$$
\begin{aligned}
& \text { NASA-TM--8991I } \\
& \text { CONF-870804--52 }
\end{aligned}
$$

NASA Technical Memorandum 89911

AIAA-87-9314

\title{
A Study of Schwarz Converters for Nuclear Powered Spacecraft
}

Thomas A. Stuart

University of Toledo

Toledo, Ohio

and

Gene E. Schwarze

Lewis Research Center

Cleveland, Ohio

Prepared for the

22nd Intersociety Energy Conversion Engineering Conference cosponsored by the AIAA, ANS, ASME, SAE, IEEE, ACS, and AIChE Philadelphia, Pennsylvania, August 10-14, 1987 


\section{DISCLAIMER}

This report was prepared as an account of work sponsored by an agency of the United States Government. Neither the United States Government nor any agency Thereof, nor any of their employees, makes any warranty, express or implied, or assumes any legal liability or responsibility for the accuracy, completeness, or usefulness of any information, apparatus, product, or process disclosed, or represents that its use would not infringe privately owned rights. Reference herein to any specific commercial product, process, or service by trade name, trademark, manufacturer, or otherwise does not necessarily constitute or imply its endorsement, recommendation, or favoring by the United States Government or any agency thereof. The views and opinions of authors expressed herein do not necessarily state or reflect those of the United States Government or any agency thereof. 


\section{DISCLAIMER}

Portions of this document may be illegible in electronic image products. Images are produced from the best available original document. 


\author{
Thomas A. Stuart \\ Department of Electrical Engineering \\ University of Toledo \\ Toledo, Ohio 43606 \\ and \\ Gene E. Schwarze \\ National Aeronautics and Space Administration \\ Lewis Research Center \\ Cleveland, Ohto 44135
}

\section{ABSTRACT}

High power space systems which use low dc voltage, high current sources such as thermoelectric generators, will most likely require high voltage conversion for transmission purposes. Th1s study considers the use of the Schwarz resonant converter for use as the basic bulloing block to accomplish this low-to-high voltage conversion for elther a dc or an ac spacecraft bus. The Schwarz converter has the important assets of both inherent fault tolerance and resonant operation and parallel operation in modular form is possible. A regulated dc spacecraft bus requires only a single stage converter while a constant frequency ac bus requires a cascaded Schwarz converter configuration. If the power system requires constant output power from the of generator, then a second converter is required to route unneeded power to a ballast load.

\section{INTROOUCTION}

Future spacecraft having electrical power requirements in excess of $100 \mathrm{~kW}$ will probably require a compact energy source such as a spacetype nuclear reactor. 1 Potentlal power converston systems for space nuclear power systems include direct energy conversion systems such as thermoelectrics or thermionics, and thermodynamic systems which convert mechanical to electrical power by means of rotary or linear alternators.

A potential problem for direct energy conversion is the low voltage and high current output of these systems. Voltage of $50 \mathrm{~V} d c$ or lower are possible dependent upon advances made with these systems. For example, a $100 \mathrm{~kW}, 100 \mathrm{~V} \mathrm{dc}$-source wlll have a current of $1000 \mathrm{~A}$, which would give elther a heavy cable with low transmission losses or a high temperature light weight cable with high transmission losses. To avold elther high cable mass or high transmission losses, it wlll be necessary to increase the transmission voltage (and thus decrease the current) by means of an electronlc converter. The term converter here will be used to designate both circults with dc-outputs and those with ac-outputs.

The voltage transmission level will also be dependent on the required separation distance between the power conversion source and the spacecraft bus. Long transmission distances will require high transmission voltages in order to obtain light weight and low loss cables. For nuclear power systems, the separation distance between the power conversion system and the spacecraft bus wtll be determined by the spacecraft's mission and a trade-off between the reactor shielding mass and the separation distance. The block diagram for a spacepower system using thermoelectric power conversion is shown in Fig. 1 .

A possible requirement of nuclear power systems such as shown in Fig. I will be the need to maintain a constant load on the reactor. One means of doing this, is to use a second converter to drive a ballast load. In this arrangement. Converter number 2 monitors the output power of the thermoelectric converter. As the spacecraft load varies. Converter number 2 varies its output such that the total output power remains constant.

This paper is concerned with the results, to date, of a study to determine approprlate types of electronic converters for this system. Any acceptable circult should at least meet the following criterla:

(1) It should be fault tolerant, 1.e., it should be able to continue to operate for at least a short time or shut down with either a short or an open ctrcuit across its output.

(2) It should operate at a high frequency to minimize magnetic component and capacitor mass.

(3) It should have a topology which minimizes component stresses and power losses.

The above criteria are very important from rellablitty and performance considerations, but they greatly reduce the number of acceptable topologles. Although improvements in other power converter circuits continues, it appears that the above criteria can be met by the Schwarz series resonant converter. A series resonant circult gives "zero" current switching which gives this converter a substantial advantage.

The basic circuit and output waveform of a Schwarz circult are shown in Figs. 2 and 3 . The circult is often called a serles resonant converter since the load is in serles with the LC resonant components. On a typlcal half cycle, $Q 2$ and $Q 3$ conduct until the current $i(t)$ reverses at $\omega_{0} t=B$ to start the next half cycle. The output voltage, $V_{0}$, can be modeled as a constant voltage that switches polarity so that it always opposes $i(t)$. Power output is controlled by vartation of the pertod, $Y$. An increase in $y$ causes a decrease in power output. An important advantage of the series resonant circuit is that $L$ and $C$ remain in series with the switching transistors, even if a short ctrcuit should occur across $v_{0}$. This means that this circult inherently meets the current fault tolerant condition since this ctrcuit will operate in a current limit

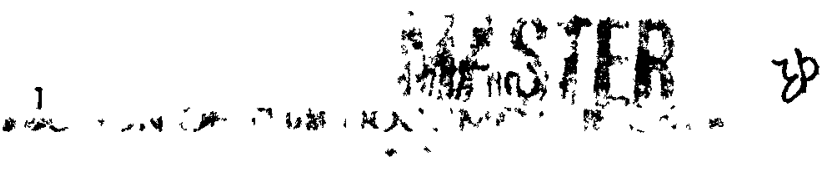


mode with $V_{0}=0$. Some types of resonant converters connect the load in parallel with $C_{\text {, in }}$ which case $C$ is discharged if a short circuit occurs. This makes fault protection much more difficult.

In sumary, this study indicates that the Schwarz converter can be used as a basic bullding black for elther dc or ac transmission systems. It also appears that it would be a particularly good candidate for hlgh power spacecraft systems because of its high efficlency and fault tolerant characteristics.

\section{ELECTRONIC CONVERTER NUMBER 1}

Although this paper is 1 imited to electronic converters of the Schwarz topologyz-10 for the bastc building blocks, this stlll allows the cholce of either a dc or an ac spacecraft power bus. The purpose of electronic Converter number 1 as shown in Fig. I is to convert the low dc voltage from the thermoelectric converter to a high voltage for transmission to the spacecraft bus. High voltage transmission is required if a low mass and low loss transmission cable is to be realtzed.

If a regulated dc bus is desired, then the power system is rather simple and only one converter stage is required as shown in Fig. 2 . However, to achleve high power levels it will probably be necessary to connect several converters in parallel from a single voltage source as shown in Fig. 4. At least one prevlous study ll shows that this type of parallel operation is feasible and it provides the advantage of both redundancy and modularization. This same arrangement of $n$ parallel converters could be used if several low voltage sources were avallable. In this case each low voltage source would feed a single converter and the parallel converter arrangement would then transmit high voltage dc to the spacecraft bus.

$D C$ transmission has an advantage in that the inductance and capacitance of the cables are of no importance, and cable design is dictated primarily by temperature and voltage requirements. OC transmission lines avoid the more complex cables required for $20 \mathrm{kHz}$ transmission 12 where series inductance increases the voltage drop and shunt capacitance increases the converter load.

As both the power levels and transmission distances increase between power source and load bus, the transmission ilne becomes an important element in the power chain. In Ref. 13, a study was made of the mass and loss characteristics of a radiation cooled dc transmission line. The geometry of the transmission line analyzed was a noninsulated solid cylindrical conductor. The transmission line in this case not only transmits the power but also acts as its own radiator by directly radiating to space the electrical power losses generated within the transmission line's conductor materlal. If the transmission line must be flexible for deployment purposes, then a cable composed of fine stranded wire may be required.

Flgure 5 uses the results of Ref. 13 and shows the transmission line's conductor mass as a func$t$ ion of the percent power loss. The percent power loss is defined as the percent of generated power converted to electrical losses. Figure 5 is plotted for a generator output. $P_{G}$, of $100 \mathrm{~kW}$, a length $L$ of $50 \mathrm{~m}$ including return line, a sink temperature of $273 \mathrm{~K}$, a view factor, $Y$, to space of 0.84 , and an emissivity, $c$, of 0.80 . The left plot is for a copper conductor line, while the right plot is for an aluminum conductor. The solld lines in the figure represent equal voltage and the dashed lines represent equal operating temperatures. For a given voltage it is seen that the conductor mass is reduced but the percent power loss is increased for increased operating temperatures. The increase in operating temperature is caused by reducing the diameter of the wire. For a given operating temperature, an increase in voltage causes both a decrease in conductor mass and percent power loss.

In Table 1 a comparison is made between a copper and an aluminum conductor dc transmission line for the same conditions used for the plots in $\mathrm{Fig}$. 5. These results show that for a given voltage and operating temperature, an aluminum conductor transmission line gives a 58 percent decrease in mass for an 18 percent increase in percent power loss and wire diameter. Since the volume of the conductor is proportional to its diameter squared, then for equal lengths, the aluminum line has 38 percent more volume than the copper line. If the means to transport the transmission iline to space is volume limited rather than mass limited, then some of the advantages of an aluminum line over a copper line begin to disappear.

The results given in Fig. 5 and Table 1 demonstrates the advantages of high voltage transmission. If the power conversion source voltage is low, then a step up Converter (Fig. 1) is needed. For example, from Table 1 it is seen that a $500 \mathrm{~V}$ line operating at $400 \mathrm{~K}$ gives both a reasonable transmission ine mass as well as a low power loss.

From a systems viewpoint it must be noted that the sum of the masses of the electronic converter and the high voltage transmission line and the combined losses of the converter and the high voltage line must be less than these same quantitles for a low voltage transmission system. It must be recognized that converters add complexity to the power transmission system and unless their use can show clear advantages, then no need exists to use them. However, if the loads require voltages other than that provided by the low voltage source, then voltage conversion will be required at the loads. Thus, for loads requiring voltage conversion, Converter number 1 could provide both high voltage transmission and distribution and the overall power system could show clear advantages in terms of mass and power savings.

If an ac spacecraft bus is required, then converter number 1 in $\mathrm{Fig}$. I could consist of two Schwarz converters connected in the cascade arrangement shown in Fig. 6. The first stage (01-Q4) is the same as the converter shown in Fig. 2 except stage (05-08) two now becomes the load. The first stage acts as a regulated oc power supply while the second stage functions as a fixed frequency ac power supply. Thus, for this cascade topology, the frequency of the ac bus voltage is fixed and its amplitude is regulated. It should be noted that the power levels between the first and second stage $15 \mathrm{dc}$. Thus, if the first stage is located at the low voltage power conversion source, and the second stage at the spacecraft power bus, then this dc link would be the high 
voltage dc transmission line and, as previously discussed, the advantage of low cable mass and electrical power loss would be realized. If stage one is located at the power conversion source which utilizes a nuclear reactor to provide its heat input, then this stage would be subjected to quite adverse environmental conditions. The converter's components would need to be shlelded against gamma and neutron fluxes or else be radtation hardened to operate effectively in this environment. It is also quite possible that stage one would also be subjected to a high temperature environment and thus, an additional stress would be imposed on the components. If the components of stage one require both shlelding and radlators to provide cooling. then the mass of the power system increases. This increase in mass must be such that locating the converter near the low voltage source shows a clear advantage in terms of power system mass and power 1055 savings. The development of high power radiation resistant and high temperature components for this type of environment could possibly negate the need for the shlelding and radiators for stage one.

An anticipated criticism of the cascaded Schwar $z$ topology is that it requires two stages of power processing, and thus causes a decrease in effictency since the overall effictency of this arrangement is equal to the product of the eff 1 clency of each stage. Inttlal laboratory results indicate that this decrease in efficlency is only about 2 to 3 percent. 11 The reason for this small decrease in efficlency is that the second stage does not include a transformer, so this stage's only significant losses are the switching losses and the losses in the resonant components $L_{2}$ and $c_{2}$. It has as yet to be fully determined whether this cascaded approach is any less efficlent compared to other approaches but it seems evident that this topology should be more rellable because of its relative simplicity.

The cascaded Schwarz converters should be designed for high-frequency operation in order to realize low mass reactive components. Lightweight, high power, high frequency space-type trans-

formers 14 and resonant capacitors 15 have been developed for converter application. In Fig. 6 it should be observed that the operating frequency of stage two is independent of the operating frequency of stage one so that each stage can be designed for different operating frequencles. The desired ac distribution bus frequency is determined by the fixed frequency osclilator driving stage two. since stage one regulates the voltage amplitude on the ac bus by varying the period, $Y$, as shown in Fig. 3, then the transformer $T_{0}$ in stage one must be designed for its lowest operating frequency in order to prevent magnetic core saturation.

An advantage of an ac distribution system is that the necessary voltage conversion for the loads can be performed by transformers and then rectified if $d c$ is required. Thus, $d c$ to $d c$ converters, which are required for dc distribution, are no longer required. These load transformers should also be operated at high frequency to achleve low mass. A fundamental question 1s: How high should the frequency be before the mass savings become insignificant? In Ref. 14 an analysis was performed to determine mass dependency on frequency. The results of this study are shown in Fig. 7. In this figure the normalized specific mass is plotted as a function of the transformer's
kVA-rating. In the figure, $a$, is the fraction of core window filled with winding conductor. Js is the load current denstty in the windings, (SF)C is the stacking factor of the core. (FF) is the voltage form factor, and $D w$ is the density of the winding conductor. Each curve in this plot represents a given frequency and for this frequency a value of magnetic flux density. $B \mathrm{~m}$. is selected so as to avold excessive specific core losses. The curves show that for a given frequency, the normalized specific mass decreases as the kVA-rating increases. Also, as the frequency is increased, the normalized specific mass decreases but the rate of decrease diminishes as the frequency increases. Thus, it is seen that from 60 to $400 \mathrm{~Hz}$ considerable mass savings result and. 11kewtse from 400 to $2000 \mathrm{~Hz}$ considerable mass savings result. However, a comparison of the 20 and $50 \mathrm{kHz}$ curves shows that minimal mass savings are realized by going to $50 \mathrm{kHz}$; so beyond $20 \mathrm{kHz}$ the mass savings become insignificant.

The shape of the waveforms that w111 appear on the ac distribution bus w111 now be discussed. If the bus and distribution lines have a relatively small shunt capacitance, then the voltage and current waveforms will be simflar to those shown in Fig. 3. However, if a $20 \mathrm{kHz}$ cable similar to that described in Ref. 12 is used for distribution of spacecraft power, then the shunt capacitance would be quite significant. The capacitance of the cable at $20 \mathrm{kHz}$ presents a large reactive load to the converter and, thus, decreases the avallable load power. Because of this, it may be necessary to connect shunt inductors across the cable to compensate for the cables capacitance. With shunt inductance added to the line, the voltage waveform would become trapezoldal in shape and not a square wave as shown in Fig. 3. This trapezoldal waveform appears to present no probiems for anticipated loads unless the loads must operate with either a sine or a square wave voltage. Heating and 11ghting loads may be able to use this distorted wave form directly, and all dc power supplies and electric motors may require rectification and flitering.

\section{ELECTRONIC CONVERTER NUMBER 2}

Since the only purpose of Converter number 2 in Fig. $i$ is to ensure a constant electrical load, then it does not matter whether its output is ac or $d c$. However, since the behavior of the Schwarz converter with its oc output is developed and understood, it would seem approprlate to use this circult to drive the ballast load. In this case, Converter number 2 would be identical to the circult in Fig. 2, although probably composed of parallel modules as shown in Fig. 4 .

\section{LOADING CONVERTER NUMBER I WITH CONVERTER NUMBER 2}

A characteristic of the Schwarz converter is that a constant output load gives an "almost" constant output frequency. The only output frequency varlations would be due to possible variations in the input voltage. It is estimated that an input voltage change of \pm 72.5 percent would cause a frequency variation of only \pm 1.9 percent.

Since the output power of both electronic converter number 1 and number 2 in $\mathrm{Flg}$. I are varlable in order to maintain constant system power, then the transformers in both of these converters need 
to operate over a variable frequency range. Reduced load conditions on the spacecraft bus would requtre the perlod $y$ (as shown in Fig. 3) of electronic Converter number 1 to increase and therefore, decrease the operating frequency of this converter's output transformer. If Converter number 2 also uses an output transformer, then the same condition applies to this output transformer when the ballast load dissipates less than full load power. For constant input voltage to Converter number 1 and number 2, the flux density of these converters transformers must increase as the frequency decreases. At light loads the flux density in these transformers will be approximately double that under full load conditions. Thus, a converter with a $20 \mathrm{kHz}$ resonant frequency must use a transformer designed for $10 \mathrm{kHz}$. As indicated above, a Schwarz converter with a constant load will have an "almost" constant output frequency. Thus, the converter's transformer can be designed for a frequency slightiy less than its resonant frequency with the result being a lighter transformer as shown in Fig. 7 .

The possibllity of realizing transformer mass savings by operating Converter number 1 with a constant load can be achleved by connecting Converter number 2 to Converter number 1 as shown in $\mathrm{Fig} .8$. The difference between the power processing circults of $\mathrm{Fig} .8$ and $\mathrm{Fig} .1$ is that Converter number 2 in $\mathrm{Fig}$. 8 operates in parallel with the spacecraft bus while in Fig. 1, Converter number 1 and number 2 operate in parallel with the thermoelectric generator.

The clrcult arrangement of the converters in Fig. 8 permits efther a dc or an ac spacecraft bus. If an ac bus is desired, then the circult configuration of $\mathrm{Fig} .8$ gains an advantage over the previousiy discussed variable frequency cascade Schwarz circult in Fig. 6. As previously indicated, a constant load on Converter number 1 gives an "almost" constant output frequency. The slight deviation in output frequency ( \pm 7.9 percent) for a \pm 72.5 percent input voltage variation is probably acceptable for ac spacecraft requirements. Hence, Converter I would require a single stage rather than the two stage arrangement shown in Fig. 6 . The elimination of stage two would result in reduced mass, power loss, and complexity.

A though the power conditioning system in Fig. 8 shows several advantages for efther an ac or dc spacecraft bus, this particular power processing scheme could present an unacceptable rellabllity problem. The potential problem is that if a short circult fault should occur across the spacecraft bus and the circuit breaker for the bus falled to respond, then both Converter number 1 and number 2 would go into their current 14 miting mode: The result would be that neither converter could deliver the full output power generated by the thermoelectric converter. The implications of this loss of electrical load on the nuclear reactor needs to be more throughly investigated before this particular power processing scheme is acceptable for future consideration as a space power processing candidate.

\section{CONCLUSION}

The resuits of this study indicate that high voltage conversion for transmission purposes may be required for dc power generators having low voltage, high current outputs. As the separation distance between the generator and spacecraft power levels increase, then high-voltage transmission is necessary in order to avold elther very heavy or very lossy transmission lines.

This study considers the use of the Schwarz series resonant converter for use as the basic bullding block to accomplish this low-to-hlgh voltage conversion for elther a dc or an ac spacecraft bus. The schwarz converter has the important assets of both fault tolerance and resonant operation and modularization of these converters for parallel operation is also possible. Parallel operation could be required for efther rellability purposes or for delivering large quantities of power to the spacecraft bus from either a single or multiple low voltage generator source.

If a dc spacecraft bus having good voltage regulation is desired, then only a single stage Schwarz converter is requtred. If an ac bus having both good voltage regulation and constant frequency is desired, then a cascaded Schwarz converter configuration is required. If the power system is required to maintain constant output power, then a second converter is required to route unneeded spacecraft power to a ballast load. If this second converter is operated in parallel with the spacecraft bus, then the spacecraft bus converter sees a constant load. This parallel operation of the bus and ballast converter leads to certain advantages not realized if the ballast converter is connected directiy to the low voltage generator source.

\section{ACKNOWLEDGMENT}

This research was sponsored in part by the NASA Lewis Research Center under Grant NAG3-708.

\section{REFERENCES}

1. Truscello, V.C. and Davis, H.S., "Nuclear Electric Power In Space," IEEE Spectrum. Vol. 21, No. 12, Dec. 1984, Pp. 58-65.

2. Schwarz, F.C., "A Method of Resonant Current Pulse Modulation for Power Converters, " IEEE Transactions on Industrial Electronics and Control Instrumentation, Vo1. 17. No. 3, May 1970, pp. 209-221.

3. Schwarz, F.C. and Klaassens, J.B., "A Controllable Secondary Multikflowatt OC Current Source With Constant Maximum Power Factor in its Three Phase Supply Line," Proceedings of the 1975 IEEE Power Electronics Specialists Conference, IEEE, New York, 1975, pp. 205-215.

4. Schwarz, F.C., "An Improved Method of Resonant Current Puise Modulation for Power Converters." IEEE Transactions on Industrial Electronics and Control Instrumentation, Vol. 23, No. 2 May 1976, PD. 133-141.

5. Schwarz, F.C. and Klaassens, J.B., "A 95 Percent Efficient $1-K W$ OC Converter with an Internal Frequency of $50 \mathrm{kHz}$ " IEEE Transactions on Industrial Electronics and Control Instrumentation, Vol. 25, No. 4, Nov. 1978, DD. 326-333. 
6. King, R. and Stuart, T.A., "A Normalized Model for the Half-Bridge Serles Resonant Converter," IEEE Transactions in Aerospace and Electronic Systems, Vo1. 17, No. 2, Mar. 1981, DP. 190-198.

7. King, R.J. and Stuart, T.A., "Modelling the Fuli-Bridge Series-Resonant Powerconverter." IEEE Transactions on Aerospace and Electronic Systems, Vol. 18, No. 4, July 1982, pp. 449-459.

8. King, R.J. and Stuart, T.A. "Transformer Induced Instablitty of the Serles Resonant Converter," IEEE Transactions on Aerospace and Electronic systems, Vol. 19, No. 3, May 1983, pp. $474-482$.

9. King, R.J. and Stuart, T.A. "Inherent overload Protection for the Series Resonant Converter," IEEE Transactions on Aerospace and Electronic Systems, Vol. 19, No. 6, Nov. 1983, pp. 820-830.

10. Robson, R.R., "The $25 \mathrm{~kW}$ Resonant $d c / d c$ Power Converter," NASA CR-168273, 1984.

11. Stuart, T.A. and Ray, B., "A High Frequency Distribution System Using Series Resonant Inverters," SCEEE/SRAP-86/26, Southeastern Center for Electrical Engineering Education, Nov. 1986.
12. Patel, M.R., "High Frequency Power O1stribution System." NASA CR-175071, 1986.

13. Schwarze, G.E., "Performance Analysis of Radiation Cooled OC Transmission Lines for High Power Space Systems," Energy for the TwentyFirst Century (20th IECEC). Vol. 1. SAE, Phlladelphta, 1985, pp. 1.252-1.269.

14. Schwarze, G.E., "Development of High Frequency Low Welght Power Magnettes for Aerospace Power Systems," Advanced Energy Systems - Their Role in Our Future (19th IECEC), Vol. 1, American Nuclear Soclety, La Grange Park, IL, 1984. pp. 196-204.

15. Renz, D.D., "High Voltage-High Power Components for Large Space Power O1stribution Systems," Advanced Energy Systems - Their Role in Our Future (19th IECEC), Vol. 1, American Nuclear Soctety, La Grange Park. IL, 1984. pp. $176-184$.

TABLE 1. - COMPARISON OF CU AND AI dc - TRANSMISSION LINE

\begin{tabular}{|c|c|c|c|c|c|c|c|}
\hline \multirow{2}{*}{\multicolumn{2}{|c|}{$\begin{aligned} P G & =100 \mathrm{~kW} \\
\mathrm{~L} & =50 \mathrm{~m}\end{aligned}$}} & \multicolumn{3}{|c|}{$T S=273 \mathrm{~K}$} & \multicolumn{3}{|c|}{$\begin{array}{l}\varepsilon=0.8 \\
Y=0.84\end{array}$} \\
\hline & & \multicolumn{3}{|c|}{$\mathrm{Cu}$ Conductor } & \multicolumn{3}{|c|}{ Al Conductor } \\
\hline$v(v)$ & $T(K)$ & $\alpha$ (percent) & $\operatorname{Mc}(\mathrm{kg})$ & $\mathrm{dc}(\mathrm{mm})$ & $\alpha($ percent) & $M c(\mathrm{~kg})$ & dc $(\mathrm{mm})$ \\
\hline 100 & $\begin{array}{l}400 \\
600 \\
800\end{array}$ & $\begin{array}{l}2.8 \\
11 \\
27\end{array}$ & $\begin{array}{r}193 \\
77 \\
43\end{array}$ & $\begin{array}{l}23.5 \\
14.9 \\
11.1\end{array}$ & $\begin{array}{l}3.3 \\
13 \\
32\end{array}$ & $\begin{array}{l}82 \\
32 \\
18\end{array}$ & $\begin{array}{l}27.8 \\
17.5 \\
13.1\end{array}$ \\
\hline 500 & $\begin{array}{l}400 \\
600 \\
800\end{array}$ & $\begin{array}{l}1.0 \\
3.8 \\
9.2\end{array}$ & $\begin{array}{l}23 \\
9.0 \\
5.0\end{array}$ & $\begin{array}{l}8.0 \\
5.1 \\
3.8\end{array}$ & $\begin{array}{l}1.1 \\
4.4 \\
11\end{array}$ & $\begin{array}{l}9.5 \\
3.8 \\
2.1\end{array}$ & $\begin{array}{l}9.5 \\
6.0 \\
4.5\end{array}$ \\
\hline 1000 & $\begin{array}{l}400 \\
600 \\
800\end{array}$ & $\begin{array}{l}0.6 \\
2.4 \\
5.8\end{array}$ & $\begin{array}{l}8.9 \\
3.6 \\
2.0\end{array}$ & $\begin{array}{l}5.1 \\
3.2 \\
2.4\end{array}$ & $\begin{array}{l}0.7 \\
2.8 \\
6.8\end{array}$ & $\begin{array}{l}3.8 \\
1.5 \\
0.8\end{array}$ & $\begin{array}{l}6.0 \\
3.8 \\
2.8\end{array}$ \\
\hline
\end{tabular}




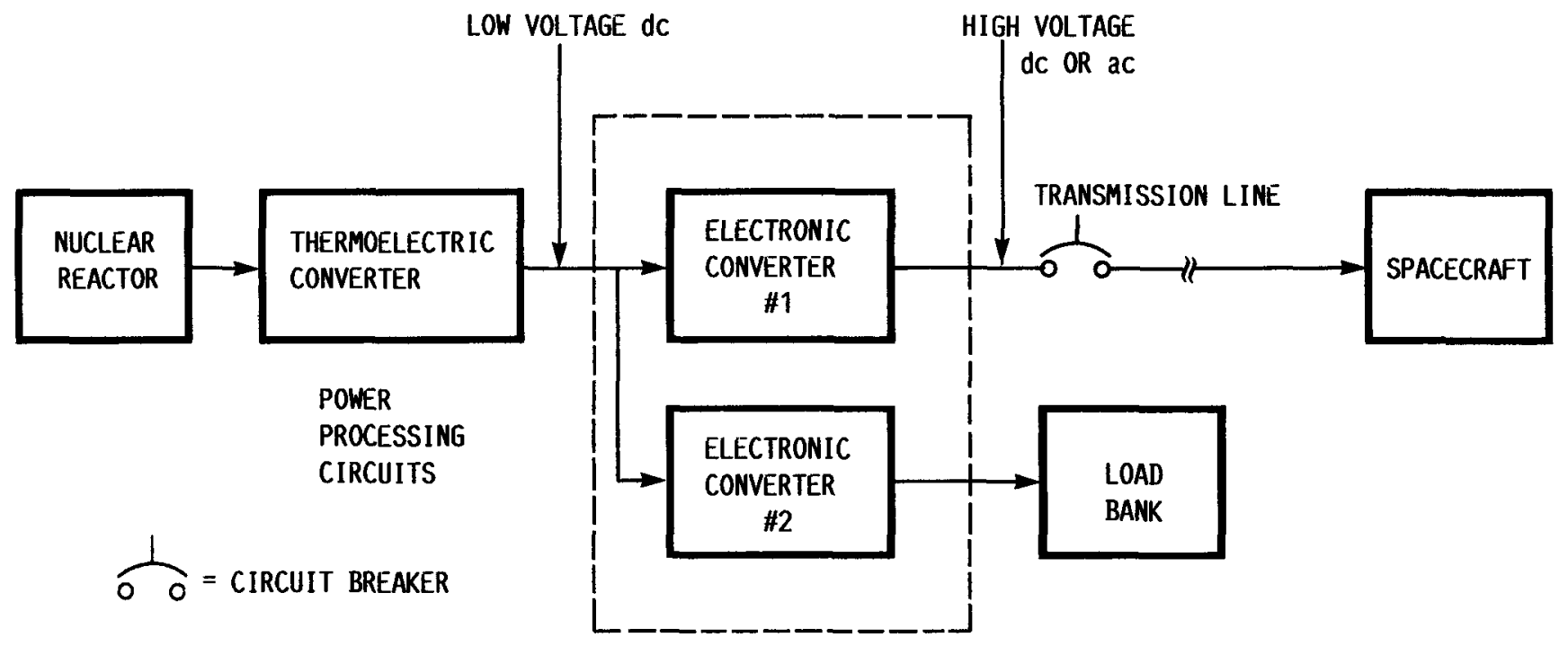

FIGURE 1. - SPACE POWER SYSTEM USING THERMOELECTRIC POWER CONVERSION.

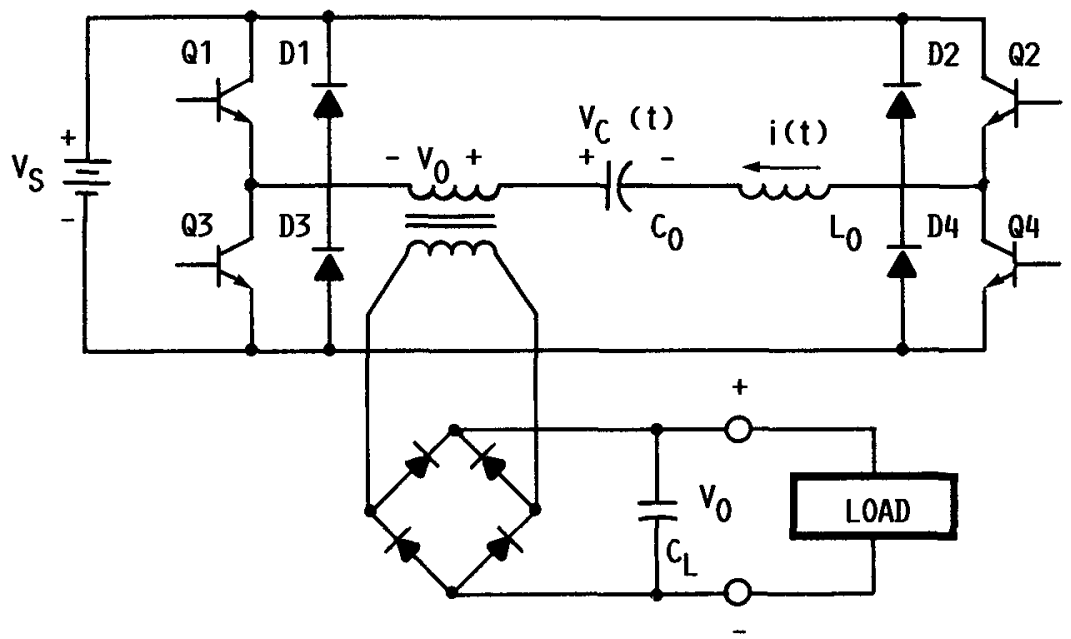

FIGURE 2.- FULL BRIDGE SCHWARZ SERIES RESONANT CONVERTER. 


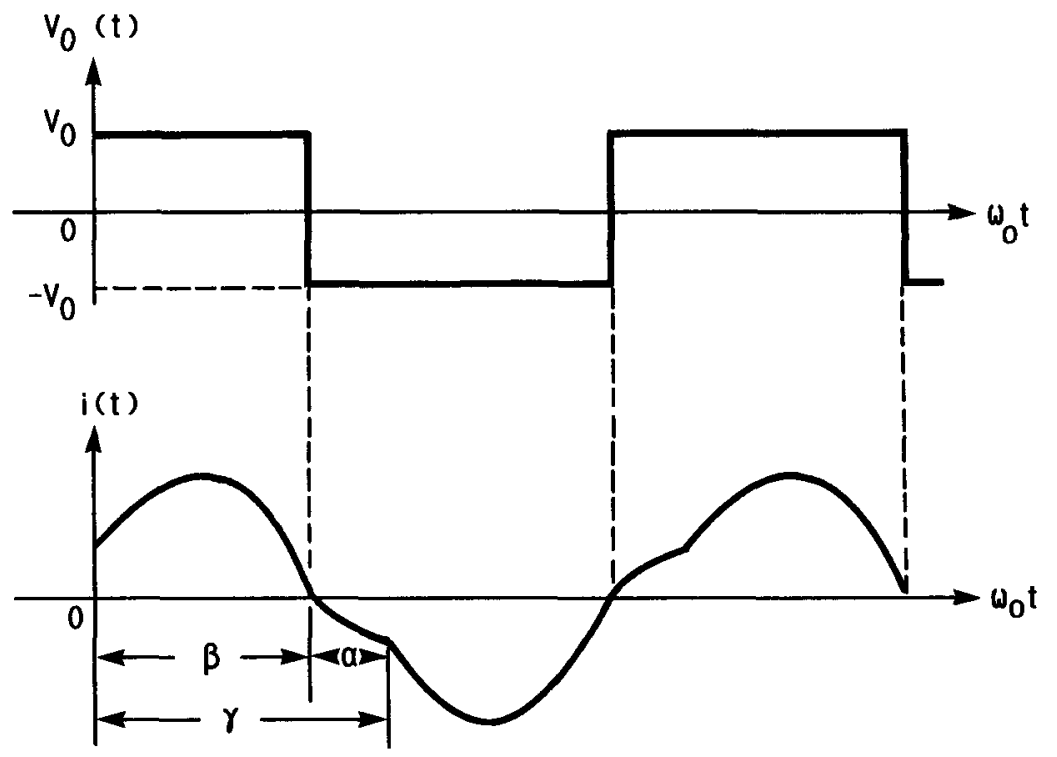

FIGURE 3. - CONTINUOUS CONDUCTION MODE LOAD VOLTAGE AND CURRENT FOR THE SCHWARZ CONVERTER.

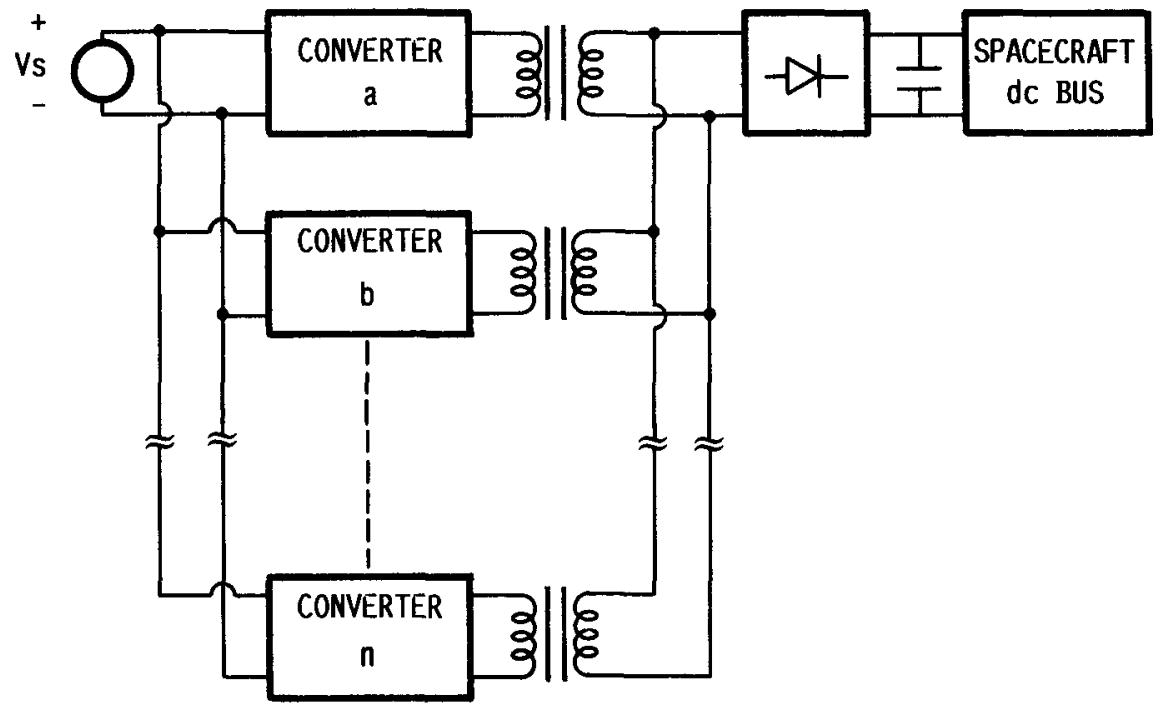

FiguRE 4. - PARALLEL CONNECTION OF $n$ SERIES RESONANT CONVERTERS. 


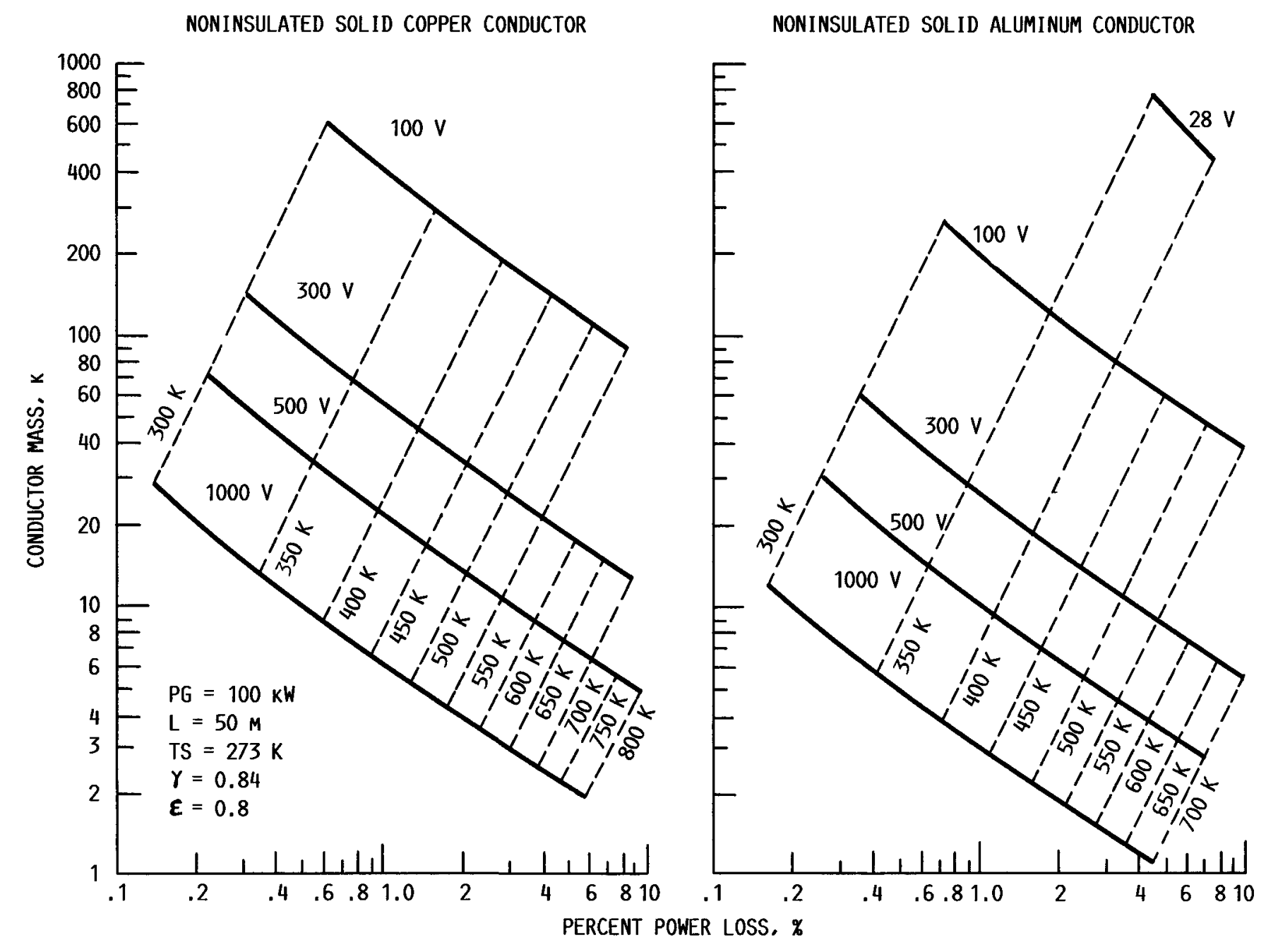

NONINSULATED SOLID ALUMINUM CONDUCTOR

FIGURE 5. - MASS VERSUS PERCENT POWER LOSS FOR A dC TRANSMISSION LINE. PARAMETERS: VOLTAGE AND OPERATING TEMPERATURE. 


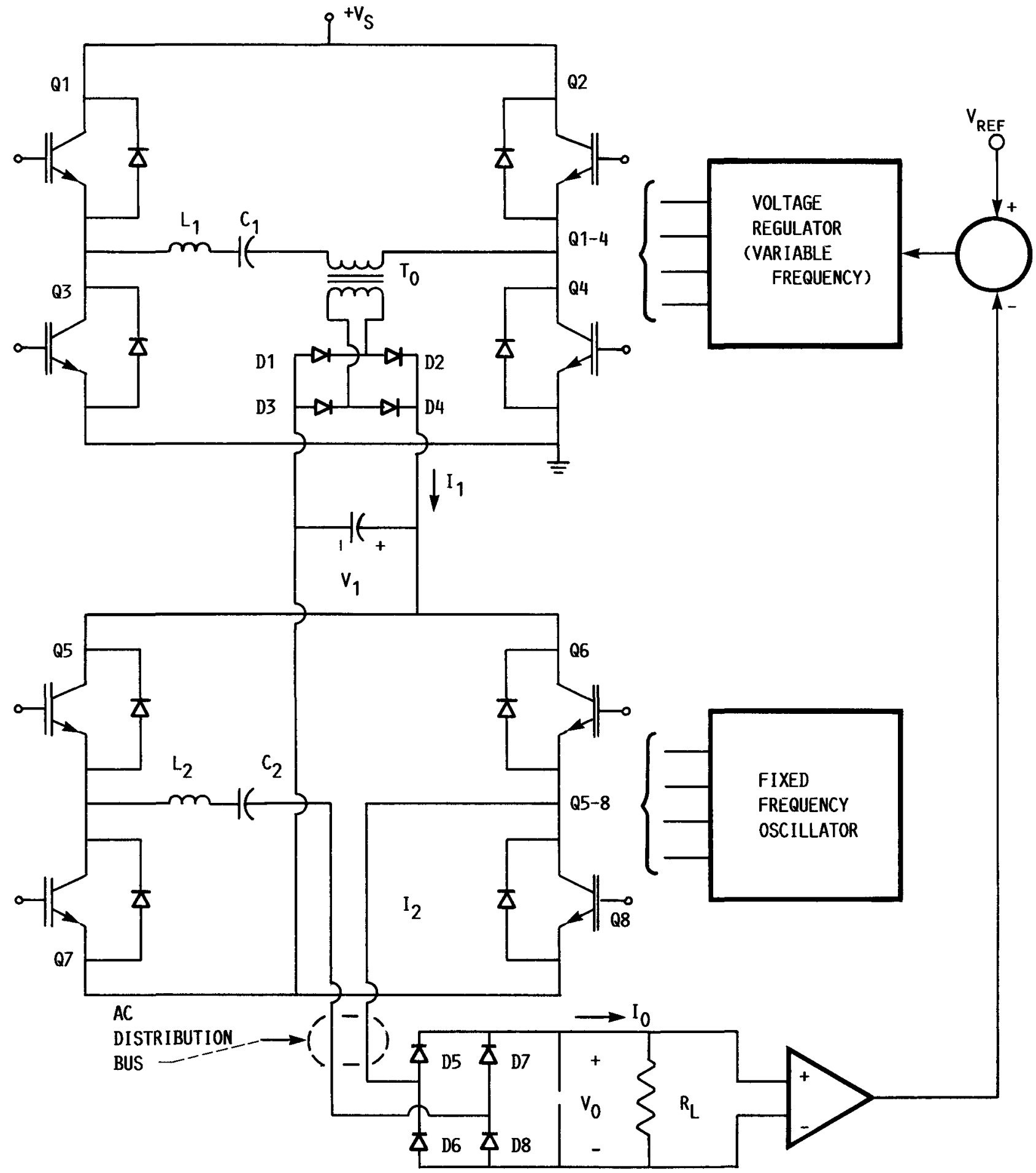

FIGURE 6. - CASCADED SCHWARZ CONVERTER WITH FIXED FREQUENCY OUTPUT. 


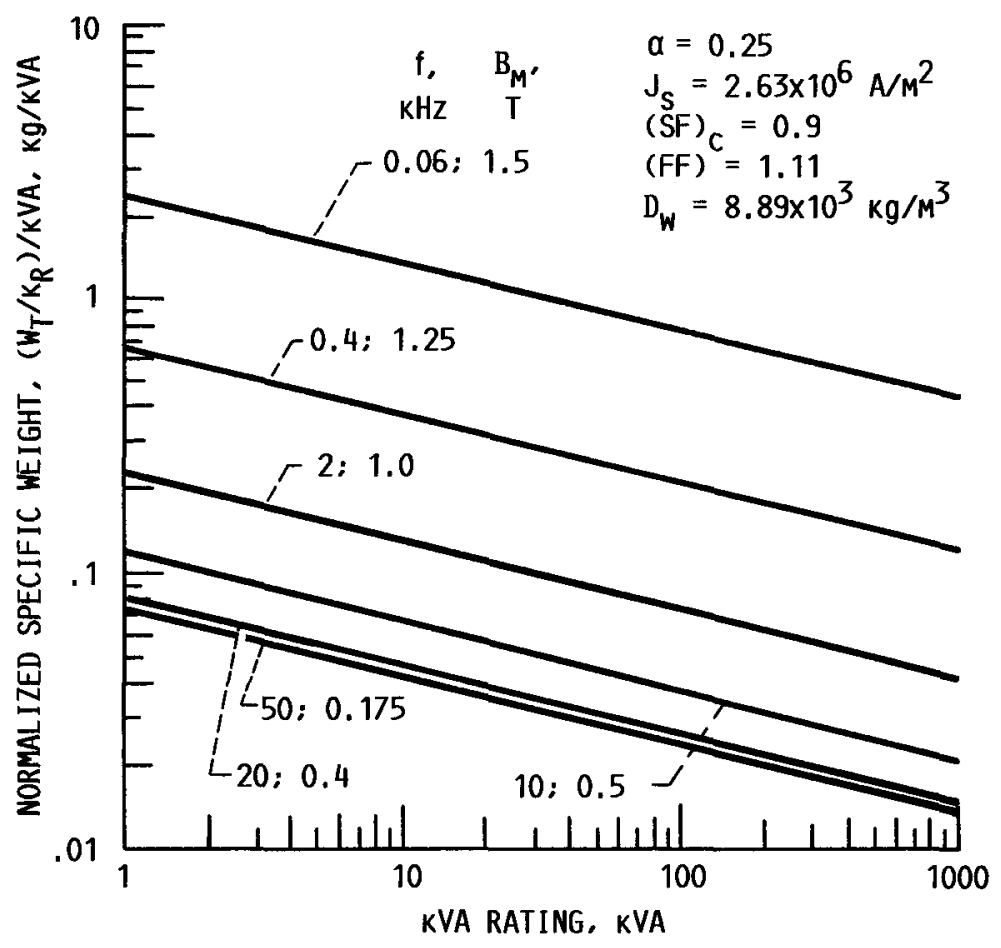

FIGURE 7. - NORMALIZED SPECIFIC WEIGHT AS A FUNCTION OF TRANSFORMER KVA RATING.

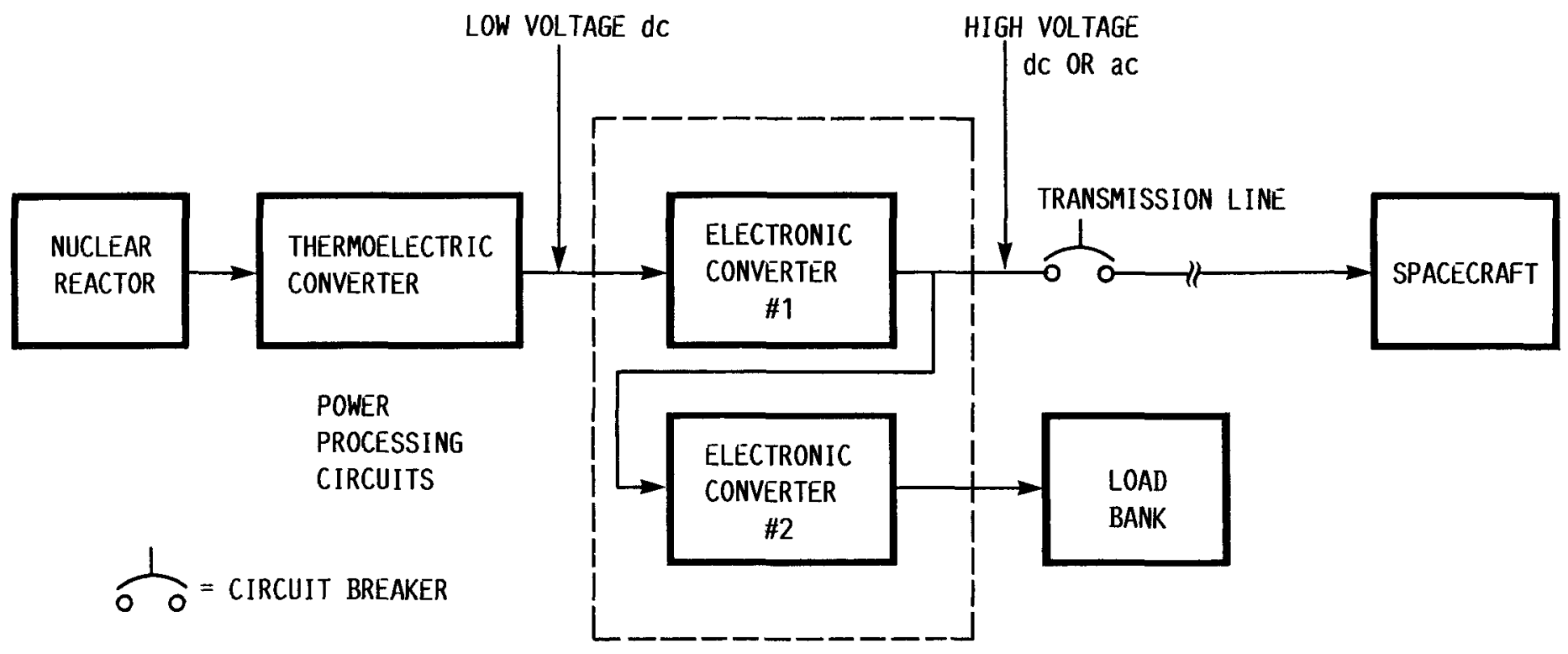

FIGURE 8. - METHOD TO OPERATE CONVERTER \#1 WITH A CONSTANT LOAD. 


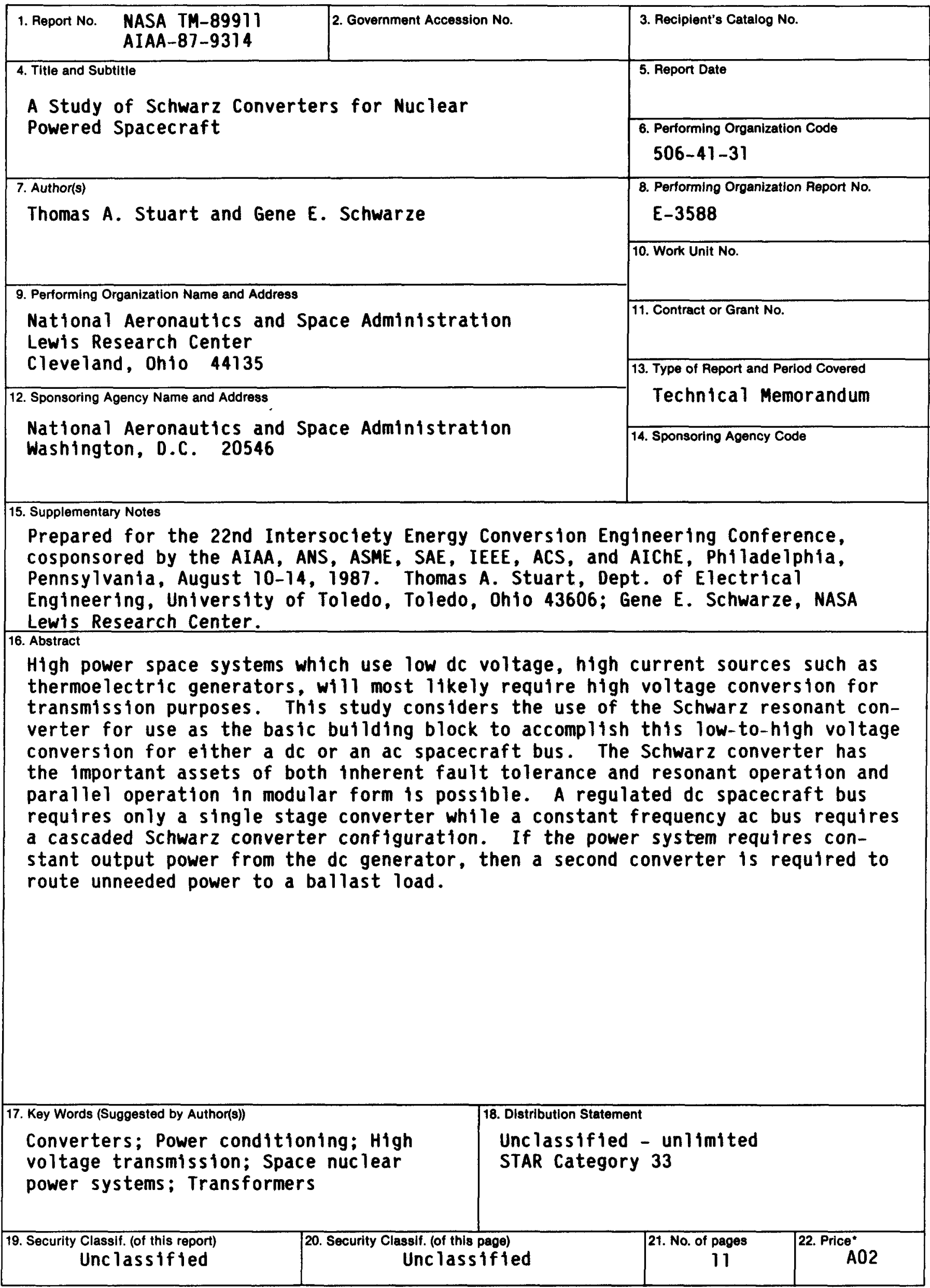

*For sale by the National Technical Information Service, Springfield, Virginia 22161 
Natıonal Aeronautıcs and Space Administration

Lewis Research Center

Cleveland. Ohıo 44135

Orictal Businase

Penaly lor Ptwate Ues $\$ \times 00$
SECONO CLASS MAIL

ADDRESS CORRECTION REQUESTED

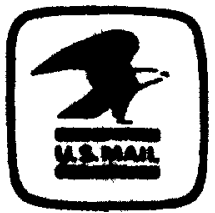

Pootage and Fees Paid National Aeronautics and Space Administration NASA-451 